\title{
International Forest Projects: Trends, Profitability and Financing ${ }^{1}$
}

by

Yves C. Dubé2

\section{Abstract}

International forest projects financed by development assistance agencies or international lending institutions, have evolved during the last 20 years from industrial forest management projects to agroforestry/ watershed conservation projects. A 1985 World Resources Institute report calls for the investment of \$8 billions US over the period 1987-91 to fight deforestation. International forest projects ex-ante rates of return are found to be well above $10 \%$. Noneconomic variables and economic variables are listed to explain a $50 \%$ discrepancy between those and expost rates of return of forest plantation projects in West Africa. The financial and economic analysis is defined and proposed to improve their financing.

Key words: Tropical forestry action plan, rates of return, common property, externalities, private and public sectors participation.

\section{Résumé}

Au cours des vingt dernières années, les projets en foresterie internationale, financés par les agences d'aide au développement et les institutions prêteuses internationales, sont passés de projets industriels d'aménagement forestier à des projets d'agroforesterie/conservation des bassins versants. Un rapport du World Resources Institue publié en 1985 , recommande l'investissement de 8 milliards \$E.U. au cours de la période 1987-91, afin de combattre la déforestation. Les taux de rendement ex ante des projets en foresterie internationale ont été établis à plus de $10 \%$. Des variables non économiques et économiques sont énumérées pour expliquer la différence de $50 \%$ observée entre ceux-ci et les taux ex post des projets de plantation forestière en Afrique de l'Ouest. L'analyse financière et économique est définie et proposée pour améliorer leur financement.

Mots-vedettes: Plan d'action forestier tropical, taux de rendement, terres publiques, externalités, participation des secteurs privé et public.

\section{Introduction}

Deforestation is certainly the most crucial issue in tropical forestry today. Every year, 11 millions hectares of tropical forest are being cleared mainly for fuelwood, shifting cultivation or cash crops; less than $2 \%$ of the cleared area is reforested. As a result, desertification follows and the very landbase supporting other economic activities may disappear in many developing countries.

The focus and importance of international forest projects financed by development assistance agencies and/or international lending institutions have changed over the past 20 years.

\section{The purpose of this paper is to:}

a) review briefly past and future trends in these projects;

b) discuss their profitability; and

c) propose a framework of analysis for their financing.

\footnotetext{
Paper presented at the 79th Annual Canadian Institute of Forestry Conference. St-John's, Newfoundland, August 5, 1987

Consultant in Forestry Economics, 11930 ave Lavigne, Montréal, Québec, Canada $\mathrm{H} 4 \mathrm{~J} 1 \times 8$
}

\section{Past Trends}

For the past two decades, development assistance to international forest projects has amounted to about $\$ 3$ billions US (CIDA, 1985). This assistance really started to increase around 10 years ago. Today, annual outlays are close to half a billion US\$. The World Bank, the US Agency for International Development, the Canadian International Development Agency and the Swedish International Development Agency represent close to $60 \%$ of total development assistance. The total amount of development assistance to international forest projects may seem important in absolute numbers. However, it represented less than $2 \%$ of public aid to development in 1985 (Table 1).

During the seventies, international forest projects were mainly in the areas of forest management and/or industrial forest projects. For example, about $47 \%$ of World Bank and $96 \%$ of CIDA forest projects were in these areas (Table 2).

\section{Future Trends}

In 1983, the FAO Committee on Forest Development in the Tropics recognized that national and international funding for tropical forestry programmes have generally decreased in 
Table 1. Annual public investment in forest projects

\begin{tabular}{lcc}
\hline Agency/Bank & $\begin{array}{c}\text { Investment } \\
\text { (millions US\$) }\end{array}$ & $\begin{array}{c}\% \text { of develop. } \\
\text { assistance }\end{array}$ \\
\hline World Bank & 106 & 0,8 \\
US Agency Inter. Develop. & 50 & 2,8 \\
(USAID) & 45 & 7,5 \\
Canadian Inter. Develop. A. & & 8,3 \\
(CIDA) & 35 & 3,2 \\
Swedish Inter. Develop. A. (SIDA) & 19 & - \\
Asian Development Bank & 15 & - \\
Japan Inter. Corporation A. & 14 & 3,7 \\
UN Develop. Program (UNDP) & 12 & 40,0 \\
FAO & 11 & 0,8 \\
Federal Republic of Germany & 10 & 0,8 \\
World Food Program (WFP) & 8 & - \\
Interamerican Develop. Bank & & - \\
(IDB) & 5 & 1,3 \\
African Development Program & 35 & \\
Organization of American States & 368 & \\
Other Bilaterals & & \\
Total & &
\end{tabular}

Source: Spears, 1985

recent years, despite the rapid rate at which forests are being cleared or degraded. It recommended that FAO establish ad hoc groups to identify and describe areas of priority and to elaborate proposals for action programmes.

Two years later, the Committee endorsed action programme proposals in the following five priority areas:

1 - forestry in land use;

2 - forest-based industrial development;

3 - fuelwood and agroforestry;

4 - conservation of tropical forest ecosystems; and

5 - institutions.

The five action programme proposals constitute the FAO's Tropical Forestry Action Plan (TFAP). Their aim is to provide the international donor community with a set of clearly defined programmes as a common reference for formulating their own tropical forestry programmes and harmonizing action between them.

The estimated level of investment required by TFAP over the next 10 years is about $\$ 15$ billions US (FAO, 1986).

Besides TFAP, the World Resources Institute (WRI), following a recommendation of the FAO Committee on Forest Development in the Tropics issued in 1985, in cooperation with the World Bank, the United Nations Development Programme, and Bilateral Aid Agencies, a report entitled: Tropical Forests: A Call for Action (WRI, 1985).

The main objective of this report was to increase both political awareness of negative effects of deforestation on human welfare and the environment, and political will to mobilize human and financial resources to fight it. It focuses on translating known solutions and strategies into a five-year programme of accelerated investment for the period 1987-91. The estimated level of public and private investment needed to make an impact on tropical deforestation during this period of time, is $\$ 8$ billions US. A quick look at this programme shows that $51 \%$ of the money would go to Asia, $30 \%$ to Latin America and $19 \%$ to Africa. It is worth stressing that $69 \%$ of planned investments are in the areas of fuelwood/agroforestry and watershed rehabilitation/conservation (Table 3 ).
According to the WRI, half of the total $\$ 8$ billions US would have to come from development assistance agencies and international lending institutions, with the remainder coming from the private sector and national governments. Investments of $\$ 800$ millions US a year in forestry and agricultural development would double the present levels of external aid.

\section{Profitability}

Profitability of international forest projects has been discussed by Sedjo (1983) and Spears (1985).

Sedjo (1983), for example, found that most of forest plantation projects he studied across the world were profitable at the level of $10 \%$. In other words, their net present value was equal to or greater than zero, using a discount rate of $10 \%$. Despite this good result, international forest projects must compare favourably with other projects. In developing countries, these other projects include agricultural/animal grazing activities which often fetch higher short-term returns. The challenge then would be to reconcile the seemingly conflicting land-uses with agroforestry systems.

The World Bank computed economic rates of return for a number of forest projects financed by the Bank over the last $10-15$ years (Table 4 ). These are well above the $10 \%$ discount rate used by Sedjo. Interestingly enough, agroforestry and environmental protection projects are earning higher rates of return than those of industrial forestry projects.

Many of these rates are ex-ante economic rates of return and compare favourably with ex-post economic rates of return. For example, many economic rates of return achieved by plantation projects in West Africa were on average $50 \%$ lower than those computed ex-ante. Two sets of variables were identified to justify the discrepancy between ex-ante and expost rates of return: a) non-economic variables and b) economic variables (Dubé, 1985).

Non-economic variables include:

- wild fires:

- animal grazing;

- low soil quality:

- inadequate rainfall;

- inadaptability of species;

- lack of technical knowledge:

- population growth;

- urbanization;

- land tenure; and

- governmental policies.

\begin{tabular}{lcc}
\hline \multicolumn{3}{l}{ Table 2. Forest projects financed by the World Bank and CIDA } \\
\hline Category of project (1968-84) & World Bank & CIDA \\
\hline \multicolumn{3}{c}{ Percentages } \\
Forest management & 9,4 & 58,0 \\
Industrial plantation & 28,3 & - \\
Processing plants & 9,4 & 38,1 \\
Fuelwood/agroforestry & 43,4 & 1,4 \\
Watershed conservation & 9,5 & 2,5 \\
Total & 100,0 & 100,0
\end{tabular}

Sources: Worid Bank, 1984 and CIDA, 1985 


\begin{tabular}{|c|c|c|c|c|}
\hline Category of project & Africa & $\begin{array}{c}\text { Latin America } \\
\text { (millions US\$) }\end{array}$ & Asia & $\%$ \\
\hline $\begin{array}{l}\text { Industrial forestry } \\
\text { Land use upland watershed } \\
\text { Ecosystem conservation } \\
\text { Fuelwood \& agroforestry }\end{array}$ & $\begin{array}{l}210 \\
191 \\
130 \\
507\end{array}$ & $\begin{array}{l}725 \\
125 \\
243 \\
490 \\
\end{array}$ & $\begin{array}{l}705 \\
915 \\
177 \\
902\end{array}$ & $\begin{array}{l}31 \\
23 \\
10 \\
36\end{array}$ \\
\hline Total & 1038 & 1583 & 2699 & \\
\hline$\%$ & 20 & 30 & 50 & 100 \\
\hline
\end{tabular}

Source: World Resources Institute, 1985

Economic variables include:

- underevaluation of forest products;

- underevaluation of recurrent costs; and

- omission of land opportunity cost in the analysis.

Amongst these variables, land tenure and underevaluation of forest products are certainly the most important.

In many developing countries, forest lands are public and this situation is usually referred to as the common property/ open-access problem in the economic literature (the tragedy of the commons). In such cases, the economic consumer does not pay the full cost associated with his use of the resource. His marginal cost corresponds to only a fraction of total marginal cost and the remainder is spread over the entire community. Revising land tenure by granting property rights is a necessary but not sufficient means of solving this problem. In effect, forest projects create extrenalities or social benefits / social costs for which an economic agent may not be rewarded or may not have to pay for, even though property rights would exist, due to market imperfections.

In practice, private enterprise will be willing to invest in a forest project only up to its expected direct benefits and no more. Unfortunately, these direct benefits are often not enough to justify the project on financial grounds although the project may be desirable on social grounds. Failure to recognize this reality has been detrimental to many forest plantation projects. Further, private objectives are associated by many with the short-term interests of society while public objectives are associated with the long-term interests of society.

Therefore, a need exists to internalize social benefits/ social costs created by forest projects in order to reconcile conflicting private ard public objectives of society and ensure long-term sustainability of these projects. Granting subsidies or raising taxes are two ways of doing this.

\section{Table 4. Profitability of some forestry projects}

\begin{tabular}{lc}
\hline Category of project & Internal rate of return \\
\hline Industrial plantation forestry & $10-15$ \\
Agroforestry/fuelwood & $15-30$ \\
Watershed convservation & $15-21$ \\
\hline
\end{tabular}

Source: Spears, 1985

In 1987, FAO published a revised version of TFAP. It is essentially the WRI accelerated investment plan with the exception of a fifth category of project: strenghtening of institutions. Only the break-form of investment by category of project change slightly.

\section{Financing}

How much a subsidy or a tax can a government (development agency) afford to grant or raise? Answering this question is tantamount to defining private and public participation in international forest projects.

The goal here is threefold:

- to ensure that every dollar allocated to forest projects is spent efficiently;

- to define private and public participation in forestry projects; and

- to grant subsidies to or raise taxes on forest projects.

The framework of analysis proposed to achieve that goal is the financial and economic analysis. Financial analysis is defined here as the discounted sum to the present of yearly monetary inflows and outflows of a project over its life. Here, one is only concerned with direct costs and revenues of the project actually incurred. This type of analysis is similar to private sector analysis. In other words, one is interested in private profitability or private objectives and not in public profitability or social objectives.

Economic analysis is similar in method to financial analysis, but it studies the project from the point of view of society and therefore, some adjustments are necessary, that is:

- external effects of the project must be internalized or taken into consideration at decision-making time;

- market prices must be replaced by shadow prices whenever the former do not reflect the true opportunity cost of production factors (because of distortions or market imperfections);

- transfer payments must be excluded of annual monetary cashflows because they do not constitute a resource use; and

- the social cost of public funds must be determined (Dubé, 1986).

Financial and economic analysis are both useful for evaluating international forest projects. For example, financial analysis will show whether a planned investment is profitable from the point of view of a private entrepreneur. If the project would not be financially profitable, a government (development agency/bank) could grant a subsidy if the social profitability of the project is acceptable. The maximum value of the subsidy would be equal to the net value of external effects and the difference between input nominal costs and social costs. In practice, negotiations would take place on the exact amount of the subsidy/tax. For example, a forest plantation project that is not financialiy profitable but has a 
positive impact on the environment, could be granted a subsidy. On the other hand, an industrial forest project that has a negative impact on the environment could be charged a tax.

Generalization of financial and economic analysis at the country level as well as the development agency/bank level would increase the likelihood of project success by:

- giving the international donor community a common basis for comparing international forest projects;

- facilitating negotiations between donor and recipient countries;

- presenting the proposal in a manner agreeable to funding agencies (either private or public);

- defining the role of private and public enterprises; and

- diversifying the risk and uncertainty.

Although the proposed framework of analysis is interesting, its application is not simple. Developing countries are chronically short money, a situation compounded by the present debt crisis. This also explains the need for doubling the level of development assistance programmes (public funds) over the next five years. On the other hand, private financial markets in developing countries are virtually nonexistent, making participation of the private sector essential.

\section{Conclusion}

The focus of international forest projects has evolved from industrial forest management projects to fuelwood/ agroforestry and conservation/rehabilitation projects over the past 20 years.

In 1985, five FAO programme proposals (TFAP) were approved to coordinate international donor community plans for action in tropical forestry. An accelerated investment plan calls for the doubling of annual public aid over the next five years.

Given the necessity of attracting private and public funds to finance forest projects and the risk and uncertainty surrounding their profitability, the successful implementation of TFAP or the accelerated investment plan implies that four basic conditions be met, namely:

- fitting forestry into national development plan;

- creation of financial and economic expertise units;

- stimulation of private investment/individual participation; and

- development of rural financial services.

The first condition is a prerequisite. In other words, it will be difficult (almost impossible) to elaborate investment plans in a sector that is not specifically identified in a country (five years) development plan. The role of the government is then to formulate national sector policies and regional action programmes, to determine level of total investments required, and to define the extent of public participation. In many developing countries, this role is jointly played by donor and recipient countries.
The second condition is closely tied to the first. In effect, once national forest policies are clearly defined, a government will need financial and economic expertise units at the national and regional levels in order to:

- identify and define forest projects in a manner acceptable to funding agencies;

- determine the financial and economic feasibility of the project;

- determine and negotiate the extent of public participation (subsidies/taxes); and

- lay the basis for the monitoring and evaluating the project.

In short, these units will be the equivalent of planning units for the project cycle with a strong financial and economic orientation. Unfortunately, developing countries often do not have all the necessary human, technical and financial resources to set up these planning units. Whenever this situation exists, development assistance and/or lending agencies play that role or should give the country the resources to play it. If these two conditions are met, then a government has the tools to formulate the extent of its participation in forest projects and consequently stimulate private investment by granting subsidies (or raising taxes for reforestation projects).

The last condition and not the least is the development of rural financial services wherever these do not exist to make feasible the participation of the private sector in forest projects, i.e., funds must be available for borrowing/lending by individual producers. Here we are facing the question of non-monetarized economy and the lack of private savings in many developing countries. In the past, development assistance agencies have got around this question by creating revolving funds.

In summary, these four conditions are seen as the minimum requirements to ensure the success of forest projects in developing countries now and in the future. In addition, involvement of the people and adequate human resources are two necessary components of these projects.

\section{References}

Canadian International Development Agency. 1985. CIDA Sector Strategy Forestry. Vol. II, Hull, Qc, Canada.

Dubé, Yves C. 1985. Analyse économique des programmes forestiers de la Banque mondiale en Afrique de l'Ouest. Mémoire de recherche. Université de Montréal.

Dubé, Yves C. 1986. Analyse financière et sociale des reboisements au Québec. Mémoire de recherche. Université de Montréal.

FAO. 1986. FAO's Tropical Forestry Action Plan. Unasylva, 38(2), 37-64.

Sedjo, Roger A. 1983. The Comparative Economics of Plantation Forestry. A Global Assessment. Resources for the Future inc. Washington, D.C.

Spears, John. 1985. Deforestation issues in developing countries. The case for an accelerated investment program. World Bank Washington, D.C.. Paper presented at the Commonwealth Forestry Conference, Victoria, B.C., Canada.

World Resources Institute. 1985. Tropical Forests: A Call for Action Parts I, II \& III. Washington, D.C.

World Bank. 1984. Economic analysis issues in Bank-financed forestry projects. Agriculture and Rural Development Department. Operations Policy Staff. 